\section{6th Congress of the International Society of Blood Transfusion}

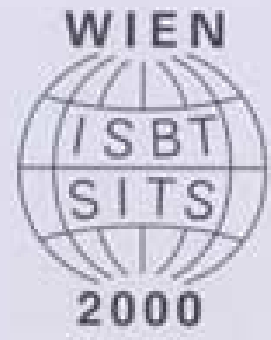

Vienna, Austria, July 9-14, 2000

Joint Congress with the

German Society for Transfusion Medicine and Immunohematology/

Deutsche Gesellschaft für Transfusionsmedizin und Immunhämatologie - DGTI and the

Austrian Society for Blood Group Serology and Transfusion Medicine/

Österreichische Gesellschaft für Blutgruppenserologie und Transfusionsmedizin - 0̈GBT

Editors: W.R. Mayr, Vienna

D.W.M. Schwartz, Vienna

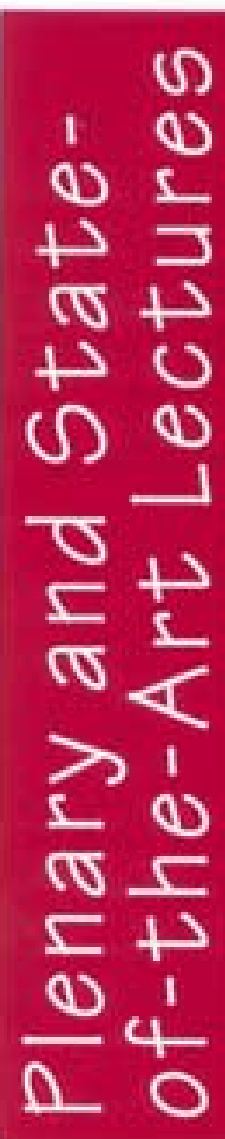

S. Karger

Mesticel and S-ientifie Publishers

Baset + Fraibury

Paris-London

Nen York + New Delh

flangkak+Singapore

Tikyo + Sydacy
KARGER

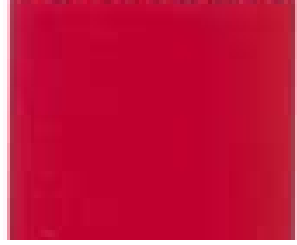

\section{nline}

Access to full text and tables of contents induding tentative ones for forthcoming isues.

www.karger.com lournalsvowlvok bi. htm 
This issue contains the Plenary and State-of-the-Art Lectures of the 26th Congress of the International Society of Blood Transfusion Vienna, Austria, July 9-14, 2000

Joint Congress with the

German Society for

Transfusion Medicine and Immunohematology/

Deutsche Gesellschaft für

Transfusionsmedizin und Immunhämatologie - DGTIand the

Austrian Society for

Blood Group Serology and Transfusion Medicine/

Österreichische Gesellschaft für

Blutgruppenserologie und Transfusionsmedizin -; ÖGBT

and is not available online for technical reasons. 